\title{
Leveraging competitiveness from sustainable operations: frameworks to understand the dynamic capabilities needed to realise NRBV supply chain strategies
}

\begin{abstract}
Purpose: This paper develops frameworks to support implementation and competitive leveraging of distinct sustainable supply chain operations. This derives from conceptual definition of the dynamic capabilities required to support Hart's (1995) natural-resource-based view resources in the supply chain.

Design/Methodology/Approach: This conceptual study uses qualitative content analysis to extract capabilities from review and analysis of literature related to natural-resource-based view and sustainable supply chain management. Intercoder reliability assessments support conceptual development of such capabilities into dynamic capability frameworks.

Findings: Specific interrelations between each natural-resource-based view resource and corresponding supply chain strategies are conceptualised. From this, capabilities are categorised to corresponding resources, dynamic capabilities activities and internal-external focus. This results in definition of 107 dynamic natural-resource-based view capabilities.
\end{abstract}

Research Implications/Limitations: Contributions are threefold: distinct frameworks for competitive sustainable supply chain management is offered; the natural-resource-based view benefits from enhanced practical guidance via definition of its dynamic capabilities, addressing the theory-practice gap; and understandings of dynamic capabilities and their role in both the natural-resource-based view sustainable supply chain management is advanced.

Practical Implications: This paper offers four frameworks to allow firms to tailor sustainability strategies to suit their needs and guide competitive leveraging. Definition of capabilities offers practical guidance to operationalise natural-resource-based view resources.

Originality/Value: This is the first holistic interpretation of natural-resource-based view capabilities and explicit application of dynamic capabilities. This forms the basis of a broader research agenda for the natural-resource-based view in sustainable supply chain management.

Key Words: Natural-resource-based view; dynamic capabilities; sustainable supply chain management.

Paper type: Conceptual study

\subsection{Introduction}

Growing ecological and societal degradation places increasing pressure on the supply chain to prioritise sustainability. However, over-saturation of sustainable supply chain management (SSCM) literature offers conflicting recommendations and strategies that impede uptake of sustainable operations (Pagell $\&$ Shevchenko, 2014). To ease this, the firm should be able to identify which areas of sustainability are most relevant to them and develop tailored strategies and capabilities to suit (Kähkönen et al., 2018). Such sustainable strategies and capabilities should be recognised as business assets (Amui et al., 2017). 
Most commonly, literature implies sustainable operations are implemented on moral, ethical or operational grounds. From this perspective, sustainable outputs are prioritised and competitive benefits considered a secondary, unintentional output. Increasing interest in the implementation of sustainability specifically for competitive gain (Berger-Walliser \& Shrivastava, 2015; McDougall et al., 2019) challenges this. This invites promotion of sustainability for competitiveness as opposed to the dominant view of competitiveness from sustainability, which may advance uptake of SSCM.

This paper applies Hart's (1995) natural-resource-based view (NRBV) and Teece's (2007) dynamic capabilities to theoretically support the competitive exploitation of sustainability in supply chain operations. The four NRBV resources (pollution prevention, product stewardship, clean technologies and base of the pyramid) facilitate conceptualisation of four distinct frameworks for competitive SSCM. Importantly, this does not seek to provide a framework for the management of competitive SSCM overall. Rather, to define the capabilities required to execute pollution prevention, product stewardship, clean technologies and base of the pyramid within SSCM only. Definition of dynamic capabilities drives practical realisation and competitive leveraging. This is explained in detail in the section below. The research question guiding this study is what are the dynamic capabilities required to support the four natural-resource-based view resources in sustainable supply chain management?

\subsection{Contextual Framing}

This paper is founded on a conceptual framework comprising three pillars: SSCM is the context of study; the NRBV is the theoretical underpinning; and dynamic capabilities offers an enabling framework for the realisation of NRBV resources in SSCM. The NRBV extends Wernerfelt's (1984) resource-based theory to a sustainability context. Resource-based theory posits that competitive resources derive from threats and opportunities in organisational activities or external environments (Barney, 1991). Building on their complexity, heterogeneity (Lockett et al., 2009), scarcity or inimitability (Powell, 1992), these resources can be exploited for competitive gain (Penrose, 1959). In the NRBV, opportunities and threats derive from ecological and societal issues to form sustainability resources for competitive exploitation. In his seminal paper, Hart (1995) conceptualised three such resources: pollution prevention, product stewardship and sustainable development. Subsequent reconceptualization divided the third resource, sustainable development, into two separate resources: clean technologies (Hart, 1997) and base of the pyramid (Hart \& Christensen, 2002). This study assumes the latter four-resource perspective of the NRBV. This recognises pollution prevention as a resource that promotes advanced minimisation of waste and pollutants (Hart \& Dowell, 1997; Shi et al., 2012) and product stewardship as a resource that prioritises sustainability throughout the lifecycle (Hart \& Dowell; Shi et al., 2012;). Clean technologies is recognised as a resource that modernises traditional systems and processes to maximise sustainability (Hart, 1997; Hart \& Dowell, 2011). Base of the 
pyramid is a resource that seeks economic and social development in emerging markets (Hart et al., 2016). As well as underpinning the implementation of sustainability for competitive gain, the application of these four resources to SSCM offers distinction that allows firms to tailor sustainable operations to suit their needs.

The emphasis on SSCM is important here and should be clearly distinguished from green supply chain management. Several studies have applied the NRBV to green supply chain management (e.g. AragonCorrea \& Sharma; Mencug \& Ozanne, 2005; Shi et al., 2012; Amui et al., 2017) to underpin competitiveness in environmental operations. Pollution prevention and product stewardship are dominant in such research, whilst clean technologies is scarcely discussed. More importantly, the environmental focus disregards the NRBV's societal base of the pyramid resource. References to social sustainability are minor are typically derive from the three-resource perspective. This overlooks the division of sustainable development into clean technologies and base of the pyramid altogether. SSCM comprises both environmental and social considerations, supporting application of a four-resource perspective of the NRBV. According to Faisal (2010), a supply chain with both environmentally and socially sustainable resources is difficult to replicate and therefore, in reference to resource-based theory, is competitively superior.

Whilst NRBV resources seek to support uptake of SSCM, SSCM also advances the NRBV. The NRBV is a prevalent theory in SSCM (Johnsen et al., 2014) but lacks practical applicability (Golicic \& Smith, 2013), resulting in a theory-practice gap (Hart \& Dowell, 2011). In particular, the capabilities required to support realisation of NRBV resources are yet to be defined. In resource-based theory, capabilities are described as 'capacities to deploy resources' (Christmann, 2000, p665) and play a central role in competitive exploitation (Amit \& Schoemaker, 1993). Scholars have long called for definition and explanation of capabilities in competitive resources (Priem \& Butler, 2001; Newbert, 2007), with the NRBV being no exception (Johnsen et al., 2014). In contrast, SSCM benefits from widespread applicability (Johnsen et al., 2014) and extensive research surrounding its implementation (Pagell \& Shevchenko, 2014). Therefore, SSCM offers valuable insights to capabilities that may support NRBV resources. This is acknowledged in recent supply chain literature that argues specific capabilities are required to form resources to meet supply chain goals (Amui et al., 2017; Dangelico, et al., 2017).

Importantly, capabilities required to support resources are subject to high levels of uncertainty and complexity (Lockett et al., 2009). This is exacerbated in the NRBV where the unpredictability of ecological and societal issues (Strauss et al., 2017) raise concerns about the feasibility and longevity of competitiveness ( $\mathrm{Li} \& \mathrm{Liu}, 2014$ ). Accordingly, there is a need for adaptability to mitigate competitive invalidity and impermanency (Hitt et al., 2015). Teece et al's (1997) concept of dynamic capabilities encourages the continuous reconfiguration and renewal of resources and offers a valuable extension to 
the NRBV (Hart \& Dowell, 2011). Dynamic capabilities activities of sensing, seizing and transforming are of particular significance. Sensing capabilities sense opportunities and threats for exploitation, seizing capabilities respond to sensed opportunities to realise competitive leveraging and transforming capabilities guide continuous reconfiguration and renewal (Teece, 2007). These activities guide definition and explanation of capabilities, extracted from SSCM, to support practical applicability and competitive leveraging of NRBV resources. Notably, grouping capabilities as activities aligns with the resource-based theory contention that combinations of capabilities (Lockett et al., 2009) form routines (Zollo \& Winter, 2002) which ultimately form resources. Moreover, dynamic capabilities is of increasing application in SSCM where it guides supply chain responsiveness (Beske et al., 2014) to sustainable and competitive operations (Dangelico et al., 2017).

This paper seeks contributions for each of the three pillars. First, contribution to SSCM derives from a new framework for distinct competitive sustainable operations. This is conceptualised by application of the four NRBV resources and three dynamic capabilities activities to SSCM capabilities to promote sustainability for competitiveness. Second, contribution to the NRBV derives from definition of the capabilities required to realise each resource, addressing the theory-practice gap. Pertinently, whilst such capabilities are not new, this is the first time they have been holistically interpreted and categorized to the four resources. Third, contributions to dynamic capabilities derives from explicit application of its three activities to competitive resources for the first time. The role and contribution of the three pillars is summarised in the table below, whilst the ensuing literature review offers expanded discussion of their interrelations.

Table 1 Pillars of the Study

\begin{tabular}{|l|l|l|l|}
\hline & Role in the Study & Justification & Contribution \\
\hline SSCM & Context of study & $\begin{array}{l}\text { Offers a wide array of sustainable } \\
\text { strategies and recommendations }\end{array}$ & $\begin{array}{l}\text { Benefits from a distinct and } \\
\text { competitively maximised } \\
\text { framework }\end{array}$ \\
\hline NRBV & $\begin{array}{l}\text { Underpinning } \\
\text { Theory }\end{array}$ & $\begin{array}{l}\text { Offers four resources to underpin } \\
\text { competitive value and add } \\
\text { distinction to SSCM }\end{array}$ & $\begin{array}{l}\text { Benefits from holistic definition } \\
\text { of dynamic capabilities to } \\
\text { overcome theory-practice gap }\end{array}$ \\
\hline $\begin{array}{l}\text { Dynamic } \\
\text { Capabilities }\end{array}$ & $\begin{array}{l}\text { Enabling } \\
\text { Framework }\end{array}$ & $\begin{array}{l}\text { Offers three activities to enable } \\
\text { resources and leverage } \\
\text { competitiveness }\end{array}$ & $\begin{array}{l}\text { Benefits from explicit application } \\
\text { of activities to competitive } \\
\text { resources }\end{array}$ \\
\hline
\end{tabular}

\subsection{Literature Review}

\subsection{Natural-Resource-Based View Resources}

As discussed, the NRBV derives competitiveness from ecological and societal issues via four resources. The competitiveness of the NRBV differs from comparable sustainability frameworks of corporate social responsibility and the triple bottom line that prioritise sustainability over competitiveness 
(Mencug \& Ozanne, 2005; Hall \& Vredenburg, 2012). Rather, the NRBV purposefully exploits competitive benefits from sustainable operations (Li \& Lui, 2014).

Pollution prevention aims to reduce costs associated with waste and maximise efficiency (Russo \& Fouts, 1997) to deliver competitive cost cutting (Hart \& Dowell, 2011). This is achieved by advanced minimisation of waste and emissions (Hart, 1995), shifting away from traditional management or disposal to prevent initial occurrence (Aragon-Correa \& Sharma, 2003). The cost cutting benefits of pollution prevention are empirically supported (Russo \& Fouts, 1997; Mencug \& Ozanne, 2005) and the resource is still considered a competitive strategy in modern literature (Miemczyk et al., 2016). Discussions of waste management in SSCM are comparable, offering consideration of efficiency and cost cutting throughout environmental planning, sourcing, manufacturing and distribution (Seuring \& Müller, 2008). However, pollution prevention seeks to go beyond the competitive outputs of such environmental operations to purposefully exploit waste as a source of competitive advantage (McDougall et al, 2019).

Product stewardship follows on from pollution prevention, extending from an internal perspective to a lifecycle perspective (Hart, 1995). As well as competitive benefits of cost cutting, this seeks access to scarce resources such as raw materials, locations or markets (Hart \& Dowell, 2011). Ecological issues such as conservation, avoidance of harmful substances and recyclability are prioritised in operations to promote stakeholder integration that cuts costs and shares resources (Miemczyk et al., 2016). Additional competitive benefits of differentiation (Ashby et al., 2012) derive from the creation of wholly, sustainable products (Golicic \& Smith, 2013). Again, comparisons can be made with SSCM where a collaborative approach is advocated (Seuring \& Müller, 2008) to encourage "planning jointly for environmental management and environmental solutions" (Vachon \& Klassen, 2008, p301). However, returning to the need for competitiveness, the competitive value of this requires greater definition, supporting application of product stewardship.

Clean technologies expands further, moving from reduced or zero impact operations towards positive impact operations. This requires development or adoption of emergent technologies or systems to modify traditional routines (Pernick \& Wilder, 2007) and drive creative redesign of industries to maximise environmentalism (Hart \& Milstein, 1999). Adopting technological advancements ahead of competitors supports competitive pre-emption (Hart \& Dowell, 2011) whilst the substitution of nonrenewables delivers cost and efficiency benefits (McDougall et al, 2019). SSCM also drives adoption of technologies (Chakrabarty \& Wang, 2012) to support a less damaging approach to production (Schrettle et al., 2014). However, this again is predominantly focused on sustainable motives, undermining the opportunity for competitive exploitation of such advancements. 
Finally, Base of the pyramid offers the socially focused counterpart of the NRBV, seeking competitive benefits via access to previously neglected and unsaturated emerging markets (Hart \& Dowell, 2011). Engaging in business with underprivileged areas presents opportunity to increase profits as such markets offer considerable opportunities for growth (London \& Hart, 1994). It also permits the exploration of radical innovations in a low risk environment (Hart \& Christensen, 2002), which if successful, can be transferred back to domestic markets (Prahalad \& Hart, 2002). Societal benefits arise in the economic development of markets at the base of the pyramid and alleviation of social ills (Hart $\&$ Christensen, 2002). Whilst the feasibility and scope of this resource has long been questioned (Kolk et al., 2014), base of the pyramid aligns with the management of social issues in the supply chain where the ultimate goal is sustainable development (Khalid et al., 2015). More explicit application of base of the pyramid may highlight the competitive potential of emerging markets, which Hart et al (2016) find to be of increasing significance.

However, as discussed the NRBV lacks practical applicability that limits its propensity to support competitive leveraging of SSCM. In spite of the intrinsic nature of resources and capabilities (Christmann, 2000), the capabilities required to realise NRBV resources are yet to be defined. Initial NRBV conceptualisation and reconceptualization only offer vague implications for capabilities, whilst subsequent theoretical elaborations neglect a four-resource perspective. For example, Aragon-Correa \& Sharma (2003) explore pollution prevention capabilities in isolation, whilst Mencug \& Ozanne (2005) overlook clean technologies and base of the pyramid entirely. Similarly, Shi et al's (2012) study of NRBV capabilities is limited to pollution prevention and product stewardship. In failing overcome the theory-practice gap (Hart \& Dowell, 2011), the NRBV falls short of the environmental revolution it was intended (Svensson \& Wagner, 2012).

\subsection{The Natural-Resource-Based View and Sustainable Supply Chain Management}

Whilst the previous section highlights NRBV-SSCM synergies, links between the NRBV and SSCM are not new. Seminal NRBV literature places a reliance on the supply chain (Hart, 1995; Johnsen et al., 2014). Both sustainability (Seuring \& Müller, 2008) and competitiveness (Prajogo \& Sohal, 2013) are realised by the chain and not by the firm. Therefore, competitive leveraging of sustainability resources requires operational support. This has stimulated previous interest in the relationship between the NRBV and the supply chain. For example, Shi et al (2012) apply pollution prevention and product stewardship to explore intra and inter-organisational environmental practices in the supply chain. Miemczyk et al (2016) investigate closed-loop supply chains from a product stewardship lens and McDougall et al (2019) offer empirical explanation of NRBV resources from exploration of the agrifood chain. However, none of these studies conceptualise specific alignments between each of the four NRBV resources and corresponding SSCM strategies. 
As discussed, such conceptualisation is a starting point in defining NRBV capabilities, building on widespread applicability (Johnsen et al., 2014) and extensive research (Pagell \& Shevchenko, 2014) of SSCM. To date SSCM capabilities are yet to be explicitly linked or categorized according to the four NRBV resources. This is also beneficial for SSCM as the four resources offer distinction and competitive exploitation of SSCM. This presents a new framework for SSCM that differs to corporate social responsibility and the triple bottom line by promoting sustainability for competitiveness. This aligns with recent literature that calls for the practical application of NRBV resources in supply chain management to support competitiveness (Yang et al., 2018; McDougall et al., 2019).

\subsection{Dynamic Capabilities Activities}

Whilst the four NRBV resources offer distinction and underpin the competitiveness of SSCM, dynamic capabilities enable competitive leveraging. Dynamic capabilities encourage firms to "integrate, build and reconfigure internal and external competencies to address rapidly changing environments" (Teece et al, 1997, p515). The continuous identification of and response to opportunities and threats (Winter, 2003 ) builds resources that are "presently scarce, difficult to imitate, nonsubstitutable and not readily available" (Powell, 1992, p552). This increases the feasibility of attaining and sustaining competitive resources (Helfat et al., 2007) and addresses concerns of invalidity or impermanency (Lockett et al, 2009). This is particularly important in the NRBV where high levels of unpredictability make competing off the back of ecological or societal issues implausible (Li \& Lui, 2014). Accordingly, dynamic capabilities offers a valuable extension to the NRBV (Hart \& Dowell, 2011) and an opportunity to support applicability of resources (Johnsen et al., 2014). In a supply chain setting, dynamic capabilities reconfiguration and renewal drives supply chain responsiveness (Beske et al., 2014; Strauss et al., 2017) and competitiveness (Kähkönen et al., 2018). This is because dynamic capabilities encourage continuous supply chain learning and, in line with resource-based theory, exploitation of opportunities (Yang et al., 2018). Importantly, recent literature considers this in a sustainability context, suggesting that dynamic capabilities help the supply chain to respond to sustainability issues (Dangelico et al., 2017) and is essential for the realisation of competitive advantage (Amui et al., 2017).

However, criticisms of obscurity (Gebauer et al., 2011) and confusion prevent application of dynamic capabilities (Johnsen et al., 2014). In particular, there is a lack of understanding of what a dynamic capability actually is. Teece (2007) contends that this represents widespread misinterpretation of dynamic capabilities. Importantly, dynamic capabilities is not a specific set of capabilities to be added on to competitive resources. Rather, dynamic capabilities is a concept focused on processes (Eisenhardt \& Martin, 1989) that guide and enable resources (Zollo \& Winter, 2002) towards reconfiguration of the resource base (Strauss et al., 2017). To clarify this, Teece (2007) defines three dynamic 
capabilities activities to enable capabilities to realise competitive resources: sensing activities, seizing activities and transforming activities.

Sensing is a "scanning, creation, learning and interpretive activity" (Teece, 2007, p1322) that recognises opportunities via entrepreneurial access to existing information or creation of new information. This is undertaken frequently to encourage market-searching efforts and anticipate market developments and changing customer needs (Gebauer, 2011). This aligns with resource-based theory's deliberate learning (Zollo \& Winter, 2002) to identify opportunities for competitive exploitation from organisational activities (Penrose, 1959) or external opportunities (Barney, 1991). In a NRBV context, this drives identification of ecological and societal opportunities. In a supply chain setting it provides a 'richness of knowledge' to grasp new opportunities (Cheng et al., 2013, p177).

Seizing activities decide which 'sensed' opportunities to invest in to growth and profitability (Teece, 2007). This is a complex and hazardous process requiring creation and adoption of new business models and effective decision-making. Accordingly, seizing happens less frequently than sensing and not all opportunities can be seized (Gebauer, 2011). Considering the NRBV, this means that whilst many ecological and societal issues may be identified in sensing, only some will be seized. Nonetheless, it enables the supply chain to 'change the business environment, the resource-base of the supply chain, or to adapt from sudden changes' (Beske et al., 2014, p141).

Transforming activities drive path-dependent organisational evolution by reconfiguring assets to enhance, combine or protect capabilities (Teece, 2007). This renews resources to adapt to changing markets and extend competitive validity and feasibility. This is undertaken continuously, requiring internal learning and capability building (Gebauer, 2011). In the context of the NRBV, transforming activities are embedded in the four resources to support continuous evolution and competitive leveraging (Strauss et al., 2017). In a supply chain setting, this drives organisational learning (Yang et al., 2018) to develop more agile and responsive supply chains (Miemczyk et al., 2016).

In this study, application of the three dynamic capabilities activities provides a framework to categorize capabilities taken from SSCM to enable the four NRBV resources. From a resource-based theory perspective, the activities represent the routines (Zollo \& Winter, 2002) or organisational skills (Grant, 1991) that form resources. This also corresponds with supply chain literature's recognition of dynamic capabilities as 'strategic tasks' (Cheng et al., 2013) to execute resources (Miemczyk et al., 2016) and sustain competitiveness (Dangelico et al., 2017). To the best of our knowledge, this is the first explicit application of sensing, seizing and transforming activities to capabilities in the NRBV. 


\section{Methods}

The aim of this paper is to conceptually define the dynamic capabilities required to support each of the four NRBV resources in SSCM. This is realised by a conceptual study comprising three phases. Phase 1 offers review and analysis of literature to identify key capabilities from NRBV-SSCM parallels. Phase 2 conceptually develops dynamic NRBV capability frameworks via reduction and refinement, categorization and sub-categorization. Phase 3 offers corroboration and reflection of the findings via consultation of recent literature.

\subsection{Phase 1 - Literature}

Review and analysis of literature comprised three stages, as depicted in figure 1, below. A traditional literature review approach was employed and supported by qualitative content analysis. Content analysis is an effective method to analyse and derive meaning from text (Burla et al, 2008), making it an appealing tool in the interpretation of literature (Tranfield et al., 2003). The researcher can "extend conceptually a theoretical framework [....] to provide predictions about the variables of interest or about the relationships among variables, helping to determine the initial coding scheme' (Hsieh \& Shannon, 2005, p1281). Here, the NRBV is conceptually extended and content analysis of NRBV and SSCM literature provided predictions about the capabilities required to support each resource. As recommended by Elo et al (2014), this was undertaken by the primary researcher and then reviewed by two researchers independently.

Stage 1 focused on NRBV literature, using the NRBV and each of its four resources as key words for literature searches. This facilitated review of 21 seminal NRBV papers ranging 1995-2017. Most prominently, these offered conceptual elaboration of NRBV resources. Whilst discussion of capabilities in these papers was limited, some capabilities implications were still identified. For example, Hart (1995) draws explicit links between total-quality-management and pollution prevention, whilst lifecycle analysis features prominently in product stewardship literature (Hart, 1995; Johnsen et al., 2014). Stage 2 sought exploration of NRBV-SSCM parallels to extract further capabilities. This facilitated review of 25 papers spanning 2007-2017 that share a focus on both the NRBV and SSCM. Of particular significance was Shi et al's (2012) paper that interprets green supply chain management as competitive resources and identifies intra and inter-organisational capabilities for pollution prevention and product stewardship. Other papers offered less explicit discussion of capabilities, but implications were again identified and strengthened via high levels of repetition. Stage 3 expanded further, exploring relevant SSCM strategies derived from stages 1 and 2 out-with a NRBV context. This invited review of 93 SSCM papers spanning 1995-2017 to extract further capabilities and ensure full saturation. Relevant SSCM strategies (see tables 1-4) served as key words for literature searches and papers with a capability focus were prioritised. For example, building on links identified in stage 2, Garg et al's (2015) paper 
on the management of closed-loop supply chains, which does not explicitly discuss the NRBV, offered insights relevant to product stewardship capabilities. In total, 213 capabilities were extracted.

Stage 1

Stage 2

Stage 3

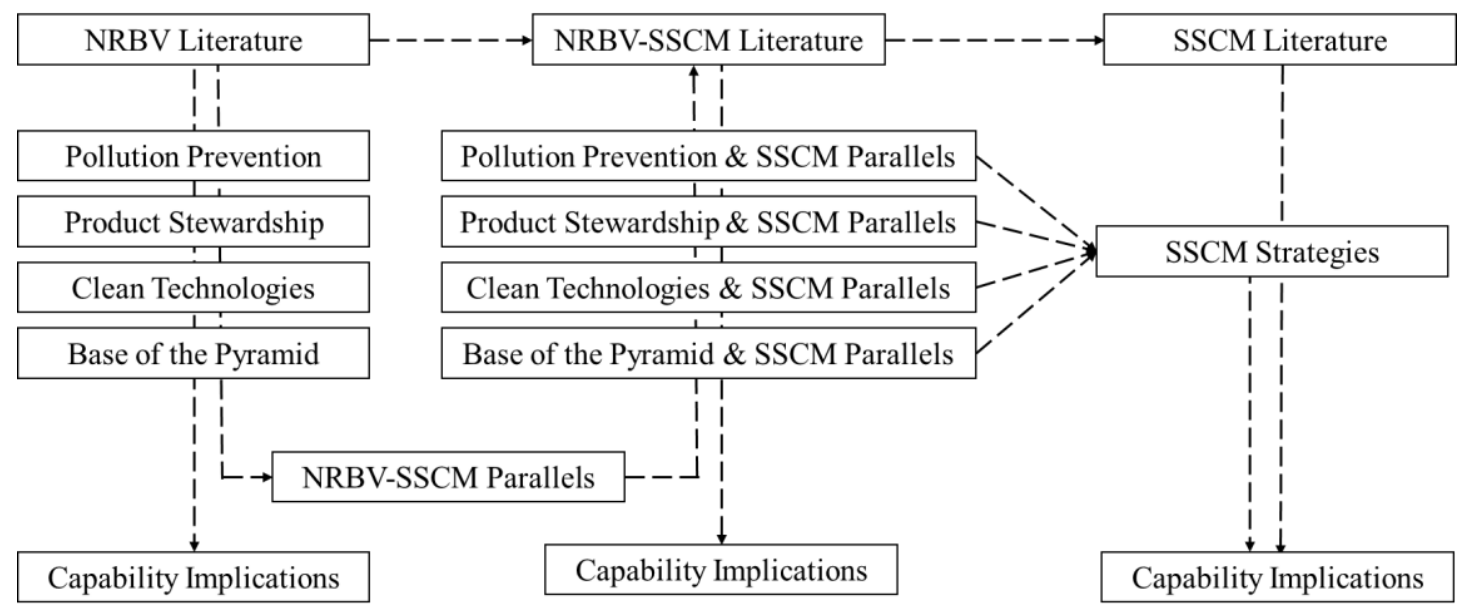

Figure 1 Process of Literature Exploration \& Capability Extraction

Importantly, clear definition of a 'capability' was essential to support validity of capabilities extracted. In this study, this sought representation from each of the three pillars. Resource-based theory defines capabilities as capacities to deploy resources to perform a task or activity or to improve performance (Teece et al., 1997) and places particular emphasis on managerial capabilities (Lockett et al., 2009). Dynamic capabilities activities of sensing, seizing and transforming were also valuable in guiding definition of capabilities relevant to this study. SSCM literature suggests that supply chain capabilities are synonymous with dynamic capabilities (Defee \& Fugate, 2010). Accordingly, Amui et al's (2017, p309) study of dynamic capabilities in the supply chain was helpful, defining capabilities as a "feature, ability, or competence to learn, improve, and adapt".

\subsection{Phase 2 - Conceptual Development}

Ackroyd (2004, p143) claims that "without adequate conceptualization it is impossible to make observations'. The conceptual development of dynamic capability frameworks was a complex process also undertaken over three stages. Intercoder reliability assessments, involving analysis by more than one researcher (Burla et al., 2008), was used to prevent bias in the data. Intercoder reliability measures 'the extent to which independent coders evaluate a characteristic of a message or artefact and reach the same conclusion' (Lombard et al., 2002, p589). Importantly, the researchers came from different academic backgrounds (marketing, operations management and sustainability), further promoting confidence in the results. 
The first stage involved reduction and refinement of capabilities extracted from literature. This was necessary as often capabilities in NRBV-SSCM were similar, resulting in repetition and confusing nomenclature. The second stage involved categorization, which according to Gbrich (2007, p21), allows data to be 'segregated, grouped, regrouped and relinked to consolidate meaning and explanation'. Capabilities were categorized to sensing, seizing of transforming activities. To promote clarity, some capabilities were renamed to reflect their dynamic role in their corresponding resource. This was undertaken manually, with the three researchers assigning capabilities to categories independently. The same process was undertaken in the third stage that further categorized capabilities to an internal versus external focus. This adds distinction to the exploitation of resources from internalities (Penrose, 1959) and externalities (Barney, 2001) and responds to calls for resource-based theory literature to distinguish between internal and external capabilities (Rashidirad et al., 2015). Internal-external categorization also acknowledges the significance of inbound and outbound activities in SSCM (Malhotra \& Mackelprang, 2012). More specifically, both internal and external capabilities are required to respond to sustainable issues (Dangelico et al., 2017).

These three stages of conceptual development resulted in final conceptual definition of dynamic capabilities for each of the four NRBV resources. Importantly, this process was complicated by the obscure presentation of capabilities in literature, which offered little insight to their specific role. This meant categorization according to dynamic capabilities activity or internal-external focus was a laborious process open to interpretation. Exacerbating this, some capabilities were relevant in more than one category. The inter-coder reliability assessment was important here. Any disparities between coding or renaming were discussed further amongst the researchers, involving in-depth discussion, interpretation, debate and further consultation of literature. As scholars suggest above $75 \%$ agreement is necessary for reliability in exploratory research (Campbell et al., 2013), all three researchers had to agree on coding and naming to include a capability in the framework. In completion, conceptual development reduced the 213 capabilities to 107.

\subsection{Phase 3 - Corroboration}

The conceptual frameworks were completed in 2017. Phase 3 directed further review of literature for two reasons. First, to corroborate the conceptual frameworks and support reliability, which is important given the conceptual nature of the study. Second, to identify additional insights and new capabilities from the fast-moving nature of the field. Accordingly, literature with explicit discussion of NRBV capabilities was prioritised. This invited review of 8 key papers spanning 2017-2020. For example, Graham's (2018) paper offered explicit discussion of prevention capabilities, whilst Bhupendra \& Sangle (2017) and Andersén et al (2019) both discuss product stewardship capabilities. Out-with a NRBV context, literature discussing capabilities for sustainability were also helpful, inviting review of a further 6 key papers. However, whilst these 14 key papers did support extraction of further 
capabilities, they did not offer elaboration. Rather, additional capabilities corroborated conceptual frameworks. This suggest saturation in the extraction of capabilities and supports the rigour of the conceptual development. Additionally, consultation of new literature corroborated NRBV-SSCM parallels and encouraged reflection of the findings.

\section{Findings \& Discussion}

\subsection{NRBV Resources \& SSCM Strategies}

This section presents relevant SSCM strategies for each of the four NRBV resources (tables 2, 3, 4 and 5). These derive from review of NRBV literature (stage 1), NRBV-SSCM literature (stage 2) and relevant SSCM literature out-with a direct NRBV context (stage 3). Literature corroborating the relevance of the strategies is also included in the analysis.

\subsubsection{Pollution Prevention \& SSCM}

As discussed, links between pollution prevention and SSCM surround advanced approaches to waste management and consequently the improved costs, efficiency, quality and environmentalism. Concerning strategies, Shi et al (2012) discuss the importance of intra-organisational practices in pollution prevention. SSCM literature suggests internal coordination (Dangelico et al., 2017) and the role of employees (Strauss et al., 2017) are particularly important in driving advanced environmentalism (Brulhart et al, 2017). Environmental management systems are prevalent (Shi et al., 2012), with clear links with pollution prevention's reliance on total quality management (Hart, 1995). In a supply chain setting, environmental management systems maximise environmental performance, reduce costs and boost competitiveness (Seuring \& Müller, 2008; Strauss et al., 2017). Lean supply chain management is also linked with pollution prevention (Galeazzo et al., 2013). By reducing or eliminating non-value activities throughout a product's entire value stream' (Hajmohammad et al., 2013, p313), lean supports advanced waste management in an environmental and competitive context (Dües et al., 2013).

Table 2 Pollution Prevention-SSCM Parallels

\begin{tabular}{|c|c|c|}
\hline \multirow{4}{*}{$\begin{array}{c}\text { Pollution } \\
\text { Prevention }\end{array}$} & Corresponding SSCM Strategy & Supporting Literature \\
\hline & $\begin{array}{ll}\text { Intra-Organisational } & \text { Environmental } \\
\text { Practices } & \end{array}$ & $\begin{array}{l}\text { Shi et al., (2012); Dangelico et al., (2017); Brulhart et } \\
\text { al., (2017); Strauss et al., (2017); Graham (2018); } \\
\text { Minbashrazgah \& Shabani (2019) }\end{array}$ \\
\hline & Environmental Management Systems & $\begin{array}{l}\text { Aragon-Correa \& Sharma (2003); Hajmohammad et } \\
\text { al., (2012); Shi et al., (2012); Ageron et al., (2013); } \\
\text { Jensen et al., (2013); Galeazzo et al., (2013); Strauss } \\
\text { et al., (2017) }\end{array}$ \\
\hline & Lean & Galeazzo et al., (2013); Hajmohammad et al., (2013) \\
\hline
\end{tabular}




\subsubsection{Product Stewardship \& SSCM}

NRBV and SSCM parallels are most obvious in product stewardship, where the shift towards externally focused operations (Hart, 1995) necessitates a supply chain focus (Miemczyk et al., 2016). The aim is to maximise environmentalism whilst improving waste, cost, efficiency and quality throughout the lifecycle. Accordingly, product stewardship relies on inter-organisational practices including green purchasing, green distribution and design for the environment (Shi et al, 2012). Links with green purchasing and distribution are reinforced by Markley \& Davis (2007), Matopoulos et al (2014) and Andersén et al (2019). Both reduce negative environmental impacts throughout the supply chain (Perotti et al., 2012) and promote efficiency, cost reduction and competitiveness (Jumadi \& Zailani, 2010). Design for the environment prioritises environmentalism throughout design processes, corresponding with initial conceptualisation of product stewardship. As well as benefits of efficiency and cost reduction, this reduces operational and technical risk (Dangelico et al., 2017).

Collaboration is central in both product stewardship (Hart, 1995;) and SSCM (Ashby et al., 2012). Sustainable supply chain collaboration is particularly important (Miemczyk et al., 2016), promoting 'the direct involvement of an organization with its suppliers and customers in planning jointly for environmental management and environmental solutions' (Vachon \& Klassen, 2008, p301). In line with product stewardship, this supports knowledge and capacity building of sustainable practices (Bhupendra $\&$ Sangle, 2018) to support environmental impacts and operations (Dangelico et al., 2017). Closed-loop supply chain management extends a collaborative sustainable approach and is also linked with product stewardship (Hart \& Milstein, 1999; Matopoulos et al., 2014). Links surround a lifecycle approach, emphasis on recyclability and reincorporation and reuse of by-products and effluents in the supply chain to create value (Garg et al., 2015). Accordingly, Miemczyk et al (2016) argue that a closed-loop approach drives successful sustainable stewardship.

Table 3 Product Stewardship-SSCM Parallels

\begin{tabular}{|c|c|c|}
\hline \multirow{6}{*}{$\begin{array}{c}\text { Product } \\
\text { Stewardship }\end{array}$} & Corresponding SSCM Strategy & Supporting Literature \\
\hline & Green Purchasing & $\begin{array}{l}\text { Markley \& Davis (2007); Shi et al., (2012); Matapolous } \\
\text { et al., (2014); Andersén et al (2019) }\end{array}$ \\
\hline & Green Distribution & $\begin{array}{l}\text { Markley \& Davis (2007); Shi et al., (2012); Matapolous } \\
\text { et al., (2014); Andersén et al (2019) }\end{array}$ \\
\hline & Design for the Environment & $\begin{array}{l}\text { Hart (1995); Markley \& Davis (2007); Shi et al., } \\
\text { (2012); Dangelico et al., (2017) }\end{array}$ \\
\hline & $\begin{array}{l}\text { Sustainable Supply Chain } \\
\text { Collaboration }\end{array}$ & $\begin{array}{l}\text { Hart (1995); Vachon \& Klassen (2008); Shi et al., } \\
\text { (2012); Johnsen } \text { et al., (2014); Miemczyk et al., (2016); } \\
\text { Dangelico et al., (2017); Bhupendra \& Sangle (2017); } \\
\text { McDougall et al., (2019) }\end{array}$ \\
\hline & $\begin{array}{l}\text { Closed-Loop Supply Chain } \\
\text { Management }\end{array}$ & $\begin{array}{l}\text { Hart \& Milstein (1999); Vachon \& Klassen (2008); } \\
\text { Ashby et al., (2012); Golicic \& Smith (2013); } \\
\text { Matopoulos et al., (2014) }\end{array}$ \\
\hline
\end{tabular}




\subsubsection{Clean Technologies \& SSCM}

Links between clean technologies and SSCM are less prominent than those of pollution prevention and product stewardship, but can be identified. Some insights derive from review of clean technologies predicating 'sustainable development' resource. For example, sustainable development is linked with corporate social responsibility (Mencug \& Ozanne, 2005; Markley \& Davis, 2007). Taking the environmental aspects of this in line with the objectives of clean technologies, corporate environmental responsibility emerges with significance, supporting proactive environmentalism (Strauss et al., 2017). More broadly, SSCM's resource efficiency is linked with the NRBV (Matopoulos et al., 2014), but is particularly relevant to clean technologies. Resource efficient supply chain management supports conservation to reduce the risk of depleted natural resource availability. This resonates with clean technologies aim to protect natural resources by substituting non-renewables with technological innovations (Hart, 1997).

The technological nature of clean technologies facilitates more explicit links with green technologies (Vachon, 2007) or sustainable supply chain technologies (Schrettle et al., 2014). Driving both technological and process advancements, these support more efficient and cleaner operations. In line with clean technologies, this can facilitate the development of a new division (Dangelico et al., 2017) to build competitive advantage (McDougall et al., 2019). Links can also be made with closed-loop supply chain management. Closed-loop supply chains create value via avoidance of limited or nonrenewable resources (Garg et al, 2015). This promotes extensive waste reduction, increased conservation and creation of renewable energies (Jensen \& Remmen, 2013), thus corresponding with clean technologies. Notably, whilst closed-loop is already linked with product stewardship, some overlap can be expected due to the interrelated nature of resources (Hart, 1997). This means resources often share common capabilities (Nath et al., 2010).

Table 4 Clean Technologies-SSCM Parallels

\begin{tabular}{|l|l|l|}
\hline \multirow{4}{*}{$\begin{array}{c}\text { Clean } \\
\text { Technologies }\end{array}$} & Corresponding SSCM Strategy & \multicolumn{1}{c|}{ Supporting Literature } \\
\cline { 2 - 3 } & Environmental SSCM Technologies & $\begin{array}{l}\text { Vachon (2007); Schrettle } \text { et al., (2014); Dangelico et } \\
\text { al., (2017); McDougall et al., (2019) }\end{array}$ \\
\cline { 2 - 3 } & $\begin{array}{l}\text { Corporate Environmental } \\
\text { Responsibility }\end{array}$ & $\begin{array}{l}\text { Mencug \& Ozanne (2005); Markley \& Davis (2007); } \\
\text { Strauss et al., (2017) }\end{array}$ \\
\cline { 2 - 3 } & Resource Efficient Supply Chains & $\begin{array}{l}\text { Bell } \text { et al., (2012); Shi } \text { et al., (2012); Matapolous et } \\
\text { al., (2014) }\end{array}$ \\
\cline { 2 - 3 } & $\begin{array}{l}\text { Slosed-Loop Supply Chain } \\
\text { Management }\end{array}$ & \\
\hline
\end{tabular}

\subsubsection{Base of the Pyramid \& SSCM}


As the most neglected resource in literature, base of the pyramid parallels again derive from the sustainable development resource and review of the social aspects of SSCM (Tate \& Bals, 2018). Considering corporate social responsibility, socially responsible supply chains are important in base of the pyramid (Matopoulos et al., 2014). Arnold and Valentin (2013) argue that the extent social responsibility is embedded into the supply chain directly affects the success of base of the pyramid. Review of literature surrounding supply chain management at the base of the economic pyramid offers further insight, particularly that which focuses on societal issues. Advanced collaboration can help to manage social issues in markets at the base of the economic pyramid (Khalid et al., 2015). This goes beyond the lifecycle collaboration linked with product stewardship to consider the wider stakeholder eco-system comprising NGOs, communities and regulators (Prahalad \& Hart, 2002; Klassen \& Vereecke, 2012). This corresponds with the global and human focused nature of base of the pyramid (Sakarya et al., 2012).

Table 5 Base of the Pyramid-SSCM Parallels

\begin{tabular}{|l|l|l|}
\hline $\begin{array}{c}\text { Base of the } \\
\text { Pyramid }\end{array}$ & Corresponding SSCM Strategy & Supporting Literature \\
\cline { 2 - 3 } & $\begin{array}{l}\text { Socially Responsible Supply } \\
\text { Chains }\end{array}$ & $\begin{array}{l}\text { Menguc \& Ozanne (2005); Markley \& Davis (2007); } \\
\text { Arnold \& Valentin (2013); Strauss et al., (2017); Tate \& } \\
\text { Bals (2018) }\end{array}$ \\
\cline { 2 - 3 } & $\begin{array}{l}\text { Supply Chains in Developing } \\
\text { Economies }\end{array}$ & $\begin{array}{l}\text { Flynn } \text { et al., (2015); Khalid } \text { et al., (2015); McDougall et } \\
\text { al., (2019) }\end{array}$ \\
\cline { 2 - 3 } & External Collaboration & $\begin{array}{l}\text { Prahalad \& Hart (2002); Khalid } \text { et al., (2015); Hart } \text { et al., } \\
\text { (2016); Ashraf et al (2018); Dembek et al (2016); Getnet } \\
\text { et al. (2019); }\end{array}$ \\
\hline
\end{tabular}

\subsection{Extraction, Conceptual Development \& Corroboration of Capabilities}

Throughout the process of reviewing literature and defining NRBV-SSCM parallels, 213 capabilities are identified with support of qualitative content analysis. 54 of these are extracted from seminal NRBV literature (stage 1). These predominantly relate to pollution prevention and product stewardship and lack empirical support or clear explanation. A further 113 are extracted from review of NRBV-SSCM parallels (stage 2) and relevant SSCM strategies out-with a NRBV context (stage 3). These benefit from greater empiricism and explanation, but lack categorization to NRBV resources. A final 46 capabilities are extracted from review of innovation literature following the emergence of innovation as a key theme in NRBV-SSCM literature.

The 213 capabilities can broadly be considered 'management capabilities' and each is linked with realisation of a NRBV resource or corresponding SSCM strategy. Conceptual development translates these capabilities from a broad, confusing list into approachable frameworks of dynamic NRBV capabilities. First, reduction and refinement eliminates 26 capabilities based on repetition and synonymy. For example, total quality management, total quality environmental management and just 
in time are refined to the holistic term 'environmental management capabilities' for pollution prevention. Second, as this study is concerned with dynamic capabilities only, capabilities that do not support sensing, seizing or transforming are also discounted, eliminating a further 80 capabilities. For example, firm size features prominently in literature as a capacity linked to attaining resources and leveraging competitiveness, but cannot be considered a dynamic capability. This leaves a more approachable list of 107 capabilities. These are then categorized according to the relevant dynamic capabilities activity and internal-external role. In completion, this study offers 21 dynamic pollution prevention capabilities (table 6); 32 dynamic product stewardship capabilities (table 7); 25 dynamic clean technologies capabilities (table 7); and 29 dynamic base of the pyramid capabilities (table 9).

These final capabilities are corroborated by review of recent literature. Specifically, 14 keys papers ranging 2017-2020 facilitate extraction of 51 capabilities. These capabilities are again subject to high levels of repetition and synonymy. Moreover, many lack dynamic capability consideration or categorization to a specific resource. However, they demonstrate clear correspondence with the conceptual frameworks.

\subsection{Conceptual Frameworks of Dynamic NRBV Capabilities}

This section presents the final frameworks of dynamic NRBV capabilities (tables 6, 7, 8 and 9). The defined capabilities form dynamic capabilities activities (sensing, seizing and transforming) to execute the four NRBV resources (pollution prevention, product stewardship, clean technologies and base of the pyramid) in SSCM (figure 2). This supports competitive leveraging of sustainable supply chain strategies. Introduction of the final capabilities and their corroboration of is offered below.

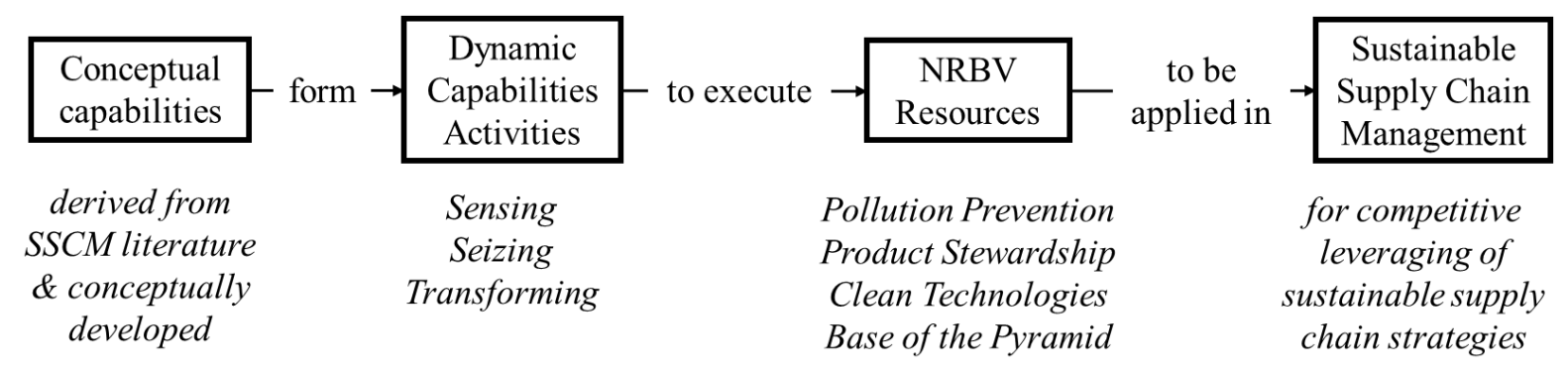

Figure 2 Representation of capabilities \& dynamic capabilities in resource execution

\subsubsection{Dynamic Pollution Prevention Capabilities}

The 35 dynamic pollution prevention capabilities in table 6 seek minimisation and competitive leveraging of waste and effluents. Sensing internal capabilities guide identification of internal areas of waste and effluents to be improved. For example, environmental, operational and financial measures and continuous improvement and optimization sense areas of waste in internal operations. This is further 
supported by cross-functional integration and technological know-how. Externally, external analysis or entrepreneurial foresight facilitates sensing in the wider market to access and develop new pollution prevention opportunities. Seizing internal capabilities such as the interpretation of environmental issues as opportunities or entrepreneurial leadership direct response to and investment in sensed opportunities. The ability to implement and manage new environmental processes and environmental management systems support adoption and operationalisation to facilitate seizing. In an external setting, external reporting and communication validates sensed opportunities to further support seizing. Transforming internal capabilities surround commitment to environmental operations via capabilities such as organisational commitment to the environment. This drives a long-term proactive approach to pollution prevention via capabilities of higher-order shared learning and creation of environmental policy and criteria. Transforming external capabilities of concern for external environments and resources and political acumen expand this to an external context for organisational evolution.

Table 6 Conceptual definition of dynamic pollution prevention capabilities

\begin{tabular}{|c|c|c|}
\hline \multicolumn{3}{|c|}{ ConceptualPollution Prevention Capabilities } \\
\hline & Internal & External \\
\hline 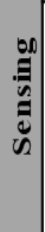 & $\begin{array}{l}\text { Environmental, operational \& financial measures } \\
\text { Continuous improvement \& optimization of processes, } \\
\text { machinery \& technologies } \\
\text { Cross-functional integration \& learning } \\
\text { Technological know-how }\end{array}$ & $\begin{array}{l}\text { Entrepreneurial foresight \& insight } \\
\text { Analysis of external environments, target markets \& changing } \\
\text { customer needs } \\
\text { Identification of environmental opportunities from } \\
\text { externalities }\end{array}$ \\
\hline & $\begin{array}{l}\text { Interpretation of environmental issues as opportunities } \\
\text { Capacity to implement \& manage new environmental } \\
\text { processes } \\
\text { Implementation of environmental management systems } \\
\text { Advanced prevention \& safety measures } \\
\text { Employee involvement, skills \& expertise } \\
\text { Entrepreneurial leadership } \\
\text { Information \& knowledge management }\end{array}$ & Evidencing reputation of environmentally sound company \\
\hline & $\begin{array}{l}\text { Organisational commitment to the environment } \\
\text { Organisational capacity to create new environmental } \\
\text { processes \& technologies } \\
\text { Creation of environmental policy \& criteria } \\
\text { Higher-order shared learning }\end{array}$ & $\begin{array}{l}\text { Political acumen surrounding environmental issues } \\
\quad \text { Concern for external environments \& resources }\end{array}$ \\
\hline
\end{tabular}

Pollution prevention corroboration principally derives from Graham (2018), who present learning and integration as key pollution prevention capabilities. Learning is central in the dynamic pollution prevention capabilities framework. This is demonstrated in capabilities of cross-functional learning, information and knowledge management and higher order shared learning. Further corroboration derives from Minbashrazgah \& Shabani (2019) definition of eco-capabilities for a NRBV dynamic capabilities paradigm. Learning is further supported, with eco-learning defined as the "firm's ability to acquire, process, and make use of information to better sense environmentally related issues" 
(Minbashrazgah \& Shabani, 2019). Integration is also prioritised in the framework at both internal and external levels. Internal integration is driven through capabilities such as cross-functional integration, employee involvement, skills and expertise and organisational commitment to the environment. External capabilities of identification of environmental opportunities from externalities and political acumen demonstrate external integration. Minbashrazgah \& Shabani (2019) also discuss integration in internal and external contexts, explicitly defining cross functional integration, green culture and relationships as dynamic eco-capabilities for the NRBV.

\subsubsection{Dynamic Product Stewardship Capabilities}

The 32 dynamic product stewardship capabilities in table 7 seek to drive coordination and competitive leveraging of environmental sustainability throughout the supply chain. This supports the creation of wholly sustainable products with environmental, economic and differentiating advantages. Sensing internal capabilities such as lifecycle analysis, incentivised environmental ideas and employee awareness promote continuous sensing of the lifecycle for environmental opportunities. Capabilities of supply chain measurement \& analysis, stakeholder integration and sharing of problems and know-how facilitate external sensing for opportunities. Seizing internal capabilities of risk taking and management of uncertainty or change encourage seizing of sensed opportunities. Implementation is supported by employee training of environmental behaviours, cross-functional integration and corporate environmental responsibility assessments. Externally, the seizing of sensed opportunities is driven by environmental, operational and financial supply chain measures and environmental audits for suppliers. Seized opportunities are operationalised by building relationships and capacity for resale, recycling or remanufacturing. Transforming internal capabilities including creation of environmental supply chain policy and cradle-to-cradle philosophy are concerned with the creation of environmental policy and circularity to guide long-term governance. Governance is also central in transforming external capabilities, where entrepreneurial leadership in the supply chain and informing suppliers about the benefits of cleaner production to encourage environmental action drive continuous environmental supply chain evolution. 


\begin{tabular}{|c|c|c|c|}
\hline \multicolumn{4}{|c|}{ Conceptual Product Stewardship Capabilities } \\
\hline & & Internal & External \\
\hline 晜 & & $\begin{array}{l}\text { Employee awareness of environmental } \\
\text { supply chain issues } \\
\text { Lifecycle perspective \& analysis of } \\
\text { products \& processes } \\
\text { Incentive systems for environmental ideas }\end{array}$ & 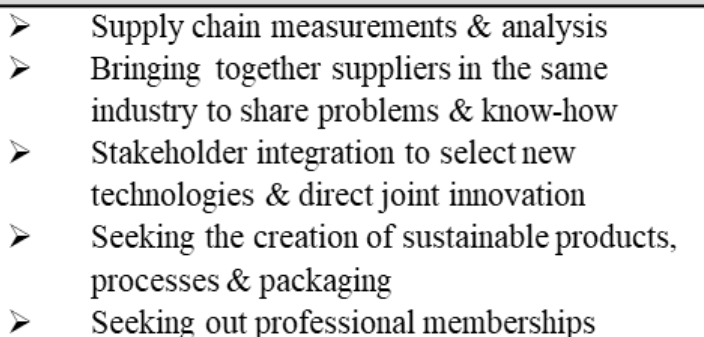 \\
\hline & $\begin{array}{l}> \\
>\end{array}$ & $\begin{array}{l}\text { Corporate environmental responsibility } \\
\text { assessments } \\
\text { Employee training surrounding } \\
\text { environmental behaviours } \\
\text { Cross-functional integration } \\
\text { Incentive systems for environmental } \\
\text { behaviours } \\
\text { Choice of suppliers by environmental } \\
\text { criteria } \\
\text { Management of uncertainty or change } \\
\text { Top management support } \\
\text { Risk taking }\end{array}$ & $\begin{array}{l}>\quad \begin{array}{l}\text { Environmental, operational \& financial supply } \\
\text { chain measures }\end{array} \\
\text { Building relationships throughout the supply } \\
\text { chain }\end{array}$ \\
\hline 昜 & $\begin{array}{l}> \\
> \\
>\end{array}$ & $\begin{array}{l}\text { Creation of environmental supply chain } \\
\text { policy } \\
\text { Vertical integration } \\
\text { Creation of recyclable or reusable products } \\
\text { Cradle-to-cradle philosophy }\end{array}$ & $\begin{array}{l}\text { Entrepreneurial leadership in the supply chain } \\
\text { Informing suppliers about the benefits of } \\
\text { cleaner production \& encouraging } \\
\text { environmental action } \\
>\quad \text { The construction of mutual goals throughout } \\
\text { the supply chain } \\
>\quad \text { Co-evolution with customers \& suppliers }\end{array}$ \\
\hline
\end{tabular}

The dynamic product stewardship capability framework corresponds with recent product stewardship studies. Bhupendra \& Sangle (2017) stress the need for absorptive capacity in product stewardship, focusing on collaboration with suppliers for new opportunities. Absorptive capacity is supported by capabilities in the framework including employee awareness of environmental supply chain issues and management of uncertainty or change. Interestingly, Hong et al (2018) suggest absorptive capacity and knowledge acquisition are key supply chain dynamic capabilities. Collaboration with new suppliers is more prominent in the framework, particularly in external sensing capabilities of supply chain measurement and analysis, bringing together suppliers to share know-how and problems and stakeholder integration to select technologies and direct joint innovation. At a seizing level, supplier collaboration is driven by building relationships throughout the supply chain, cooperation with suppliers for environmental objectives and new lower impact operations and choice of suppliers by environmental criteria. Andersén et al (2019) offer further support, suggesting supplier selection for green cooperation is a key capacity in product stewardship. Transforming also facilitates collaboration via the construction of mutual goals throughout the supply chain and co-evolution with customers and 
suppliers. Out-with absorptive capacity and supplier collaboration, Andersén et al (2019) highlight the need for CEO and top management support in product stewardship, whilst Minbashrazgah \& Shabani (2019) define top management green sensitivity as a dynamic eco-capability in the NRBV. This supports the emphasis on incentive systems for environmental ideas and environmental behaviours and creation of environmental policy in the framework. More explicitly, top Management Support is defined in the framework as a seizing dynamic product stewardship capability.

\subsubsection{Dynamic Clean Technologies Capabilities}

The 25 dynamic clean technologies capabilities defined in table 8 seek creation and competitive leveraging of new processes and systems for positive-impact operations. Sensing internal capabilities such as continuous assessment and improvement of environmental impact and green research and development sense opportunities from research, analysis and interpretation of environmental impacts. Externally, opportunities are sensed by supplier environmental impact audits, consumer and environmental consultation and seeking advanced reduction of energy and material consumption. Internal capabilities such as investment in innovations of the future encourage the seizing of sensed clean technologies. Implementation is supported by employee technological know-how and skills and implementation of technological and quality management systems. Seizing external capabilities of supplier guidance and sharing and creating new technologies extend this throughout the supply chain and wider environment. Transforming internal capabilities such as aptitude for disruptive change, strategic planning for the future and eco-design encourage continuous innovation of processes, systems and policies in pursuit of long-term positive impacts. Transforming external capabilities encourage a global perspective and inter-organisational learning of positive impacts via political acumen and knowledge transfer and capacity building.

Table 8 Conceptual definition of dynamic clean technologies capabilities

\begin{tabular}{|c|c|c|}
\hline \multicolumn{3}{|c|}{ Conceptual Clean Technologies Capabilities } \\
\hline & Internal & External \\
\hline 昙 & $\begin{array}{ll}> & \text { Continuous assessment \& improvement of environmental } \\
\text { impact }\end{array}$ & $\begin{array}{l}\text { Consumer \& environmental consultation of new technologies \& } \\
\text { innovations } \\
\text { Seeking the advanced reduction of energy \& material } \\
\text { consumption } \\
\quad \text { Supplier environmental impact audits }\end{array}$ \\
\hline 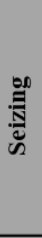 & $\begin{array}{l}>\quad \begin{array}{l}\text { Organisational capacity to implement, manage \& create clean } \\
\text { technologies }\end{array} \\
>\quad \text { Implementation of technological \& quality management } \\
\text { systems } \\
>\quad \text { Environmental, \& financial \& measures } \\
>\quad \text { Employee technological know-how \& skills } \\
\end{array}$ & $\begin{array}{l}\text { Supplier guidance surrounding clean technologies \& positive } \\
\text { impact operations } \\
\text { Sharing \& creating new technologies throughout the supply chain }\end{array}$ \\
\hline 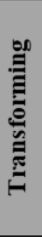 & 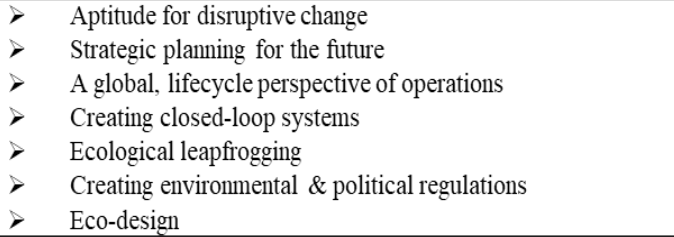 & $\begin{array}{ll}> & \text { Commercialization of clean technologies } \\
> & \text { Political acumen surrounding clean technologies } \\
& \text { Knowledge transfer \& capacity building throughout industry }\end{array}$ \\
\hline
\end{tabular}


Clean technologies is the least discussed resource in literature ranging 2017-2020, but some capabilities are still corroborated. Most explicitly, Ashraf et al (2018) discuss the need for incentivisation, knowledge sharing and a culture for change in the adoption of clean technologies. Knowledge sharing is central in the clean technologies framework, implicated in capabilities across all three activities and in both internal and external contexts (employee awareness of green technologies; consumer and environmental consultation of new technologies and innovation; employee technological know-how; supplier guidance surrounding clean technologies and positive impact operations; knowledge transfer and capacity building). Incentivisation is less prominent, but corresponds with commercialization of clean technologies. A culture for change is supported by capabilities such as green research and development, investment in innovations of the future and aptitude for disruptive change. Offering further support, Minbashrazgah \& Shabani (2019) identify technology sensing and response as a dynamic eco-capability for the NRBV. From a broader NRBV perspective, proactive commitment to the environment (Brulhart et al., 2017), environmental public concern and eco-innovativeness (Minbashrazgah \& Shabani, 2019) are identified as NRBV capabilities. These resonate with transforming dynamic clean technologies capabilities.

\subsubsection{Dynamic Base of the Pyramid Capabilities}

The 29 dynamic base of the pyramid capabilities defined in table 9 support the management and competitive leveraging of operations in markets at the base of the economic pyramid. Sensing internal capabilities encourage continuous scanning for new markets and social issues for opportunities via integration of internal resource to direct $R \& D$ and employee awareness of social issues and sustainability benefits. External sensing is facilitated by monitoring external environments, nontraditional collaboration and joint planning with stakeholders and externalities and customer consultation of social issues. Seizing internal capabilities such as translating innovations in business proposals, strategic market entry and entrepreneurial power of employees and individuals encourage seizing of sensed opportunities. Seized opportunities are implemented with support of internal assessment and auditing of social practices and impact and validated by fair trade certification and principles. External seizing is encouraged by rewards and penalties for supplier social practice and use of social media to promote social practices and communicate with society. External capabilities of loyal and committed relationships with externalities and generating resources from donations, grants, volunteers or intellectual property support implementation. Transforming internal capabilities install a socially sustainable philosophy via a global perspective of business and society and employee commitment and top management support for social improvement. This helps to adapt to new markets and social issues on a continuous basis. Transforming external capabilities encourage continuous interorganisational social development via promotion of sustainability benefits, scaling and replication to create systematic social change and co-invention and spread of resources. 
Table 9 Conceptual definition of dynamic base of the pyramid capabilities

\begin{tabular}{|c|c|c|c|}
\hline \multicolumn{4}{|c|}{ Conceptual Base of the Pyramid Capabilities } \\
\hline & & Internal & External \\
\hline 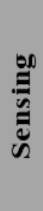 & & $\begin{array}{l}\text { Integration of internal resources to direct R\&D \& identify } \\
\text { new markets \& technologies } \\
\text { Employee awareness of social issues \& social } \\
\text { sustainability benefits }\end{array}$ & $\begin{array}{l}\text { Monitoring external environment to identify new markets \& } \\
\text { social issues } \\
\text { Non-traditional collaboration \& joint planning with } \\
\text { stakeholders and externalities } \\
\text { Customer consultation of social issues }\end{array}$ \\
\hline & & $\begin{array}{l}\text { Internal assessment \& auditing of social practices \& } \\
\text { impact } \\
\text { Attaining fair trade certification \& principles } \\
\text { Supplier selection to meet social criteria } \\
\text { Strategic market entry } \\
\text { Capacity for new technologies \& innovations } \\
\text { Capacity for product \& process customisation } \\
\text { Entrepreneurial power of employees and individuals } \\
\text { Translating innovations into business proposals }\end{array}$ & $\begin{array}{ll}> & \text { Undertaking supplier assessment \& auditing of social } \\
\text { practices }\end{array}$ \\
\hline 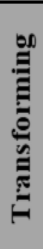 & & $\begin{array}{l}\text { Assuming a global perspective of business \& society } \\
\text { Employee commitment \& top management support for } \\
\text { social improvement } \\
\text { Access to information } \\
\text { Vertical integration }\end{array}$ & $\begin{array}{l}\text { Promotion of social sustainability benefits } \\
>\quad \text { Scaling \& replication to create systematic social change } \\
\text { Co-invention \& spread of resources } \\
\text { Awareness of regulatory framework in base of the pyramid } \\
\text { markets } \\
\text { Information transparency }\end{array}$ \\
\hline
\end{tabular}

Base of the pyramid benefits from the greatest corroboration of dynamic capabilities. This is significant as base of the pyramid is considered the least studied NRBV resource (Hart et al., 2016). In particular, four studies discuss the need for external collaboration in base of the pyramid (Asheraf et al., 2018; Dembek et al., 2018; Tate \& Bals, 2018; Getnet et al., 2019). This supports capabilities of nontraditional collaboration and joint planning with externalities, building loyal and committed relationships with externalities, co-invention and spread of resources and awareness of regulatory framework at the base of the economic pyramid. This also corresponds with Hong et al's (2018) presentation of social network relationship ability as a supply chain dynamic capability. Additionally, recent literature calls for an understanding of social needs, mission driven approach (Tate \& Bals, 2018) and recognising value at base of the pyramid (Getnet et al., 2019). This corresponds with capabilities including employee awareness of social issues and social sustainability benefits, monitoring external environments to identify new markets and social issues and employee commitment and top management support for social improvement. Social innovation (Tate \& Bals, 2018) and marketing capacity (Getnet et al, 2019) are also discussed in recent base of the pyramid literature. This supports capabilities of strategic market entry, translating innovations into business proposals, generating resources from donations, grants, volunteers or intellectual property and scaling and replication to create systematic social change. According to Hong et al (2018), a market-orientated perspective is a supply chain dynamic capability. Other base of the pyramid capabilities include internal governance and metrics, 
staff management, developing social strategies and supply chain collaboration and monitoring (Tate \& Bals, 2018). These demonstrate further correspondence with the dynamic base of the pyramid capability framework.

\subsection{Reflection}

Phase 3 (review of literature spanning 2017-2020) invites reflection on the findings. It is particularly interesting that in the period 2017-2020 there appears an increase in studies focused on capability definition in NRBV resources. Importantly, many of these benefit from empirical support, advancing applicability of the resources. However, the four-resource perspective remains lacking. Similarly, whilst studies often refer to dynamic capabilities and the need for adaptability, explicit application of sensing, seizing and transforming is overlooked. The distinction between internal and external capabilities is also acknowledged but rarely applied. Accordingly, increasing interest in NRBV capabilities supports the relevance of this study, whilst the novelty of the four-resource, dynamic capabilities activities and internal-external categorization offers important theoretical implications.

From a SSCM perspective, literature ranging 2017-2020 suggests that interest in capabilities for sustainable operation also continues to expand. However, the high level of repetition and synonymy of capabilities reinforces claims that research in this area is over-saturated (Pagell \& Shevchenko, 2014). Importantly, the 107 capabilities offered in the frameworks are primarily extracted from SSCM literature. Therefore they are not new and do not seek to represent SSCM capabilities overall. Rather, they represent SSCM capabilities that have been holistically interpreted as dynamic capabilities for each of the four resources for the first time. They seek to enable NRBV resources for competitive exploitation within SSCM. The significance of this is supported in recent literature. Literature ranging 2017-2020 implies growing interest in competitive resources and dynamic capabilities in the supply chain. This supports competitive exploitation of sustainability and the shift from competitiveness from sustainability to competitiveness for sustainability, which the frameworks aim to realise.

\subsection{Theoretical \& Practical Implications}

The conceptual frameworks above address the aim of this paper: to conceptually define the dynamic capabilities required to support each of the four NRBV resources in SSCM. In addition, intended theoretical contributions are realised for each of the three pillars of the study: SSCM, NRBV and dynamic capabilities.

\subsubsection{Theoretical Contributions}

Theoretical contributions for SSCM derive from new conceptual frameworks for distinct, competitive sustainable operations. As discussed, the frameworks do not seek to represent SSCM capabilities overall. Rather, the application of NRBV resources, dynamic capabilities activities and internal-external 
categorization offers new frameworks to promote distinction and competitive exploitation of sustainable operations. There are several important theoretical implications here. First, the competitive value of sustainable supply chain strategies is brought to the forefront and theoretically supported by the NRBV. This promotes a sustainability for competitiveness argument, aligning with growing interest in the implementation of sustainability specifically for competitive gain (Berger-Walliser \& Shrivastava, 2015; McDougall et al., 2019). Second, the four resources distinguish between the excess of SSCM strategies to offer four distinct frameworks, each with specific sustainability focus. This expands beyond broad NRBV-SSCM links to conceptualise specific interrelations, offering stronger explanation of the role of competitive resources in SSCM. Third, application of dynamic capabilities promotes much needed understanding in how ecological and societal opportunities are sensed and seized for competitive exploitation in SSCM. Transforming capabilities expand this, guiding organisational evolution to sustain competitiveness in SSCM. This explicit definition offers significant elaboration to existing efforts to understand the role of dynamic capabilities in promoting sustainability and competitiveness in a supply chain context (e.g. Amui et al, 2017; Kähkönen et al., 2018; Yang et al., 2018). Finally, distinction is further promoted by internal-external categorization. The need for internal and external capabilities in SSCM is often acknowledge but rarely defined. Clear understanding of both is required to support supply chain flexibility (Malhotra \& Mackelprang, 2012) and competitiveness (Dangelico et al., 2017). Moreover, as the external focus expands between frameworks insights are offered to the dyadic and triadic nature of different SSCM strategies.

Theoretical contributions for the NRBV principally derive from definition of 107 capabilities to realise NRBV resources. This is the first comprehensive definition of dynamic capabilities for each of the four resources. Building on the central role of capabilities in resource-based theory (Christmann, 2000), this offers long over-due practical guidance to address a theory-practice gap. Whilst the defined capabilities are conceptual, their extraction from SSCM supports practical applicability. This is because SSCM benefits from widespread applicability (Johnsen et al., 2014) and comprehensive implication for capabilities (Pagell \& Shevchenko, 2014). Application of the three dynamic capabilities offers further value. To the best of our knowledge, this is the first explicit application of sensing, seizing and transforming to define capabilities for competitive resources. The deconstruction of resources into activities and then capabilities is important here. This exemplifies seminal arguments that combinations of capabilities (Lockett et al., 2009) form routines (Zollo \& Winter, 2002) which ultimately form resources. This offers clarification to the complex yet fundamental role of capabilities in competitive resources that has long confused academics (Rashidirad et al., 2015). Moreover, by embedding continuous resource reconfiguration and renewal via dynamic capabilities, this study supports the plausibility of attaining NRBV resources and sustaining competitiveness. Thus, definition of dynamic capabilities for each NRBV resources contributes to existing efforts to support practical application of NRBV resources in SSCM to support competitiveness (Yang et al., 2018; McDougall et al., 2019). 
Internal-external categorization offers further theoretical elaboration. This acknowledges the internal and external nature of competitive resources (Lockett et al, 2009) and responds to calls for distinction between the two contexts (Rashidirad et al., 2015). Along with dynamic capabilities, this highlights the important role of internal and external capabilities in resource building and reconfiguration to support competitive and sustainable operations.

Finally, theoretical contributions are offered to dynamic capabilities. As discussed, this study is the first to explicitly apply dynamic capabilities activities to NRBV resources. This transitions dynamic capabilities from an obscure resource-based theory extension to an enabling framework to guide, explain and execute NRBV resources. Recognising dynamic capabilities as a concept dismisses the misinterpretation of dynamic capabilities as a specific set of capabilities and challenges criticisms of inapplicability and obscurity (Gebauer, 2011; Johnsen et al., 2014). In a SSCM context, this study elaborates on existing efforts to better understand dynamic capabilities in a supply chain context. In particular, categorization of SSCM capabilities to dynamic capabilities activities adds definition to claims that the two are synonymous (Defee \& Fugate, 2010).

\subsubsection{Practical Implications}

Practical implications also arise from the conceptual frameworks. Frameworks for each of the four resources offer distinction to sustainable operations. This helps managers to identify which areas of sustainability are important to them and develop strategies and capabilities to support this. For example, the dynamic pollution prevention framework supports the pursuit of internal advanced waste management and environmental operations, whilst the dynamic product stewardship framework extends environmental operations throughout the supply chain. The dynamic clean technologies framework offers further extension towards positive impact operations, whilst the dynamic base of the pyramid framework can be prioritised by firms focused on social sustainability. This responds to calls for greater distinction and personalisation of sustainable operations (Kähkönen et al., 2018). In a NRBV context, this corresponds with a recent study by McDougall et al (2019) which finds NRBV resources are implemented individually or in any order to suit the specific needs of the firm. Definition of dynamic capabilities deconstructs resources for managers to guide adoption and competitive leveraging of each resource. That is, sensing capabilities direct identification of relevant opportunities and seizing capabilities encourage response to such opportunities and support their implementation. Transforming capabilities drive continuous evolution to extent the competitive feasibility and longevity of the chosen resource. Internal-external categorization is important here, promoting intelligibility and approachability. More specifically, this encourages managers to look inside and outside the firm for opportunities for exploitation and develop capabilities to respond at both internal and supply chain levels. Accordingly, NRBV, dynamic capability and internal-external categorization means that 
managers can select groupings of key capabilities to prioritise areas of sustainability, align with the progression of the firm or respond to identified internal or external weaknesses.

Beyond practical guidance, the prioritisation of competitiveness in the frameworks incentivises uptake of sustainable operations. This shifts from competitiveness from sustainability where sustainable operations are considered a necessary evil, towards sustainability for competitiveness where sustainable operations support cost, efficiency, quality and competitive differentiation goals. Motivation to adopt sustainable supply chain strategies is of considerable practical significance as pressure to respond to ecological and societal degradation increases.

\subsubsection{Limitations and Future Research}

Importantly, theoretical and practical contributions are limited by the conceptual nature of this study. Neither the NRBV-SSCM parallels nor the defined dynamic NRBV capabilities offered in this paper have been empirically verified. Rather, the 107 capabilities serve as the first step of a broader research agenda for the NRBV in SSCM. This prioritises empirical investigation of NRBV resources and capabilities in SSCM and welcomes further augmentation of the frameworks. This should seek more than reinforcement of this paper's findings to offer empirical elaboration of pollution prevention, product stewardship, clean technologies and base of the pyramid in SSCM. Definition of common capabilities would also be interesting and help to address the theory-practice gap. Whilst the four resources offer distinction to sustainable operations, operationalisation of the NRBV based on 107 capabilities is arguably convoluted. The value of common capabilities is discussed in resource-based theory (Nath et al., 2010) and dynamic capabilities literature (Eisenhardt \& Martin, 1989) and may maximise approachability and applicability. Out-with a NRBV context, definition of common capabilities may further support refinement of SSCM capabilities in response to confusion and oversaturation.

Future research of resources and dynamic capabilities out-with a NRBV context is also invited. The NRBV is one of many resource-based theory adaptations. The complex relationship between resources, capabilities and competitiveness is not unique to the NRBV. Rather confusion surrounds resource-based theory on the whole (Barney, 2001; Priem \& Butler, 2001) and is considered the key limitation of the theory (Grant, 1991; Rashidirad et al., 2015). In particular, Lockett et al (2009) suggest that researchers have struggled with the study of resources and capabilities due to their obscure nature. This paper's explicit application of dynamic capabilities activities and internal-external categorization offers a template for methodological replicability to advance understandings of resource-based theory adaptations other than the NRBV. 
NRBV limitations offer further avenues for future research. Queries surrounding the feasibility of base of the pyramid as a competitive resource are particularly interesting. These typically surround disparities between the global focus on emerging markets and the wider social sustainability context that emphasises locality (Kolk et al, 2014). Nonetheless, Tate \& Bals (2018) discuss the increasing significance of social sustainability as a competitive resource, introducing the social-resource-based view. Moreover, a recent study by McDougall et al (2019) conceptualises 'local philanthropy' as a new resource to suggest that social sustainability in the NRBV exists out-with a base of the pyramid context. Expanding on this, exploration of social sustainability in a competitive, supply chain context is also prioritised in the future research agenda.

The role of innovation in the NRBV a presents an interesting topic for future research. As discussed, the literature review identified innovation as a key theme in NRBV-SSCM parallels. This is demonstrated in papers by Mencug \& Ozanne (2005), Shi et al., (2012), Cheng et al. (2013) and Johnsen et al. (2014). This encouraged review of innovation literature to extract 46 capabilities in this study. However, conceptualisation of specific interrelations between NRBV resources and innovation typologies fall out-with the scope of this paper and warrant greater attention. Reinforcing this, interrelations between dynamic capabilities, environmental resources and innovation have featured in recent supply chain literature (Dangelico et al., 2017).

Similarly, whilst the theoretical basis of this study is focused on the NRBV and dynamic capabilities, implications for additional theories warrant consideration. First, institutional theory may expand understanding of 'social, economic and political resources in order to adapt to specific institutional environments in view of enhancing firm performance' (Yang \& Su, 2014, p721). Institutional theory contends that business activities are not necessarily rational in a business sense but are instead driven by the wider institutional environment (Hahn \& Kühnen, 2013). This offers support for the prioritisation of sustainability in the frameworks and has encouraged links with the NRBV in existing studies (Shi et $a l$, 2012). Second, stakeholder theory supports an emphasis on managerial practices (Co \& Barro, 2008) to help firms meet end objectives (Polonsky et al., 1995). This reinforces the significance of capabilities and the presentation of the natural environment as a key stakeholder in the frameworks. Stakeholder theory has already been linked with resource-based theory (Sarkis et al., 2010), the NRBV (Hart, 1995; Hart \& Dowell, 2011) and institutional theory (Lee, 2011; Hahn \& Kühnen, 2013). Future research from an institutional or stakeholder theory lens may invite clarification of the triadic nature of NRBV resources in SSCM.

Finally, the context of this study must be considered. This paper defines the dynamic capabilities required to realise NRBV resources via supply chain strategies. Accordingly, it does not seek to provide a framework for the management of competitive SSCM overall. Given the scope of SSCM and 
competitiveness, this would be impossible. Rather, this study defines the capabilities required to execute pollution prevention, product stewardship, clean technologies and base of the pyramid within SSCM only. This means capabilities defined are specific to their corresponding resource. Strategies adopted across different areas of sustainable operations will differ and will involve different capabilities. This should be considered in the context of the supply chain and interrelations between different actors. Issues of conflict, risk and trade-off offer further avenues for future research.

\section{References}

Ackroyd, S. (2004) "Methodology for management and organisation studies: some implications for critical realism". In: Fleetwood, S., Ackroyd., S. Critical Realist Applications in Organisation and Management Studies. London: Routledge, pp127-150.

Amit, R. and Schoemaker, P.J.H. (1993) "Strategic assets and organisational rents", Strategic Management Journal, Vol 14 No. 1, pp33-46.

Amui, L.B.L., Jabbour, C.J.C., de Sousa Jabbour, A.B.L and Kannan, D. (2017) "Sustainability as a dynamic organisational capability: a systematic review and a future agenda toward a sustainable transition", Journal of Cleaner Production, Vol 142, pp308-322.

Andersén, J., Jansson, C. and Ljungkvist, T. (2019) 'Can environmentally orientated CEO's and environmentally friendly suppliers boost the growth of small firms?' Business Strategy \& the Environment, 29 (2) pp325-334

Aragon-Correa, J.A. and Sharma, S. (2003) "A contingent resource-based view of proactive corporate environmental strategy", Academy of Management Review, Vol 28 No. 1, pp71-88.

Arnold, D.G. and Valentin, A. (2013). "Corporate social responsibility at the base of the pyramid", Journal of Business Research, Vol 66 No. 10, pp1904-1914.

Ashby, A., Leat, M. and Hudson-Smith, M. (2012) "Making connections: a review of supply chain management and sustainability literature", Supply Chain Management: An International Journal, Vol 17 No. 5, pp497-516.

Ashraf, N., Comyns, B., Arin, G.A. and Bhatti, Z.A. (2018) 'The roles of network embeddedness, market incentives and slack resources in the adoption of clean technologies by firms in developing countries'. Climate Policy, 19 (5) pp556-570

Barney, J.B. (1991) "Firm resources and sustained competitive advantage", Journal of Management, Vol 17 No. 1, pp99-120.

Barney, J.B. (2001) "Resource-based theories of competitive advantage: a ten year retrospective on the resource-based view", Journal of Management, Vol 27 No. 6, pp643-650.

Berger-Walliser, G. and Shrivastava, P. (2015) "Beyond compliance: sustainable development, business \& proactive law", Georgetown Journal of International Law, Vol 46 No. 2, pp417441.

Bell, J.E., Mollenkopf, D.A. and Stolze, H.J. (2012) "Natural resource scarcity and the closed loop supply chain: a resource advantage view", International Journal of Physical and Distribution Management, Vol 43 No. 5/6, pp351-379.

Beske, P. Land, A. and Seuring, S. (2014) "Sustainable supply chain management practices and dynamic capabilities in the food industry: a critical analysis of the literature", International Journal of Production Economics, Vol 152, pp131-143.

Burla, L., Knierim, B., Barth, J., Liewald, K., Duetz, M. and Abel, T. (2008) "From text to codings: intercoder reliability assessment in qualitative content analysis", Nursing Research, Vol 57 No. 2, pp113-117. 
Butler, J.E. and Priem, R.L. (2001) "Is the resource based "view" a useful framework for strategic management research?", Academy of Management Review, Vol 26 No. 1, pp22-40.

Brulhart, F., Gherra, S. and Marais, M. (2017) 'Are environmental strategies profitable for companies? The key role of natural competences from a resource-based view'. Management Decision, 55 (10) pp2126-2148

Campbell, J.L., Quincy, C., Osserman, J. and Pedersen, O.K. (2013) "Coding in-depth semi-structured interviews: problems and unitization and inter-coder reliability", Sociological Research \& Methods, Vol 42 No. 3, pp294-320.

Chakrabarty, S. and Wang, L. (2012) "The long-term sustenance of sustainability practices in MNCs: A dynamic capabilities perspective of the role of R\&D and Internationalization". Journal of Business Ethics, Vol 110 No. 2, pp205-217.

Chen, I.J. and Kitsis, A.M. (2017) 'A research framework of sustainable supply chain management: the role of relational capabilities in driving performance'. The International Journal of Logistics Management, 28 (4) pp1454-1478

Cheng, J., Chen, M. and Huang, C. (2013) "Assessing inter-organisational performance through relational governance and dynamic capabilities in the supply chain", Supply Chain Management: an International Journal, Vol 19 No. 2, pp173-186.

Christensen, C.M. (1997) The innovators dilemma: When new technologies cause great firms to fail. Boston: Harvard University Press

Christmann, P. (2000) "Effects of "best practices" of environmental management on cost advantage: the role of complementary assets", The Academy of Management Journal, Vol 43 No. 4, pp663680 .

Co, H.C. and Barro, F. (2008) "Stakeholder theory and dynamics in supply chain collaboration", International Journal of Operations and Production Management, Vol 29 No. 6, pp591-611.

Dangelico, R.M., Pujari, D., Pontrandolfo, P. (2017) "Green product innovation in manufacturing firms: a sustainability-orientated capability perspective", Business Strategy \& the Environment, Vol 26 No. 4, pp490-506.

Defee, C.C. and Fugate, B.S. (2010) "Changing perspectives of capabilities in the dynamic supply chain era”, The International Journal of Logistics Management, Vol 21 No. 2, pp180-206.

Dembek, K., York, J. and Singh, P. (2018) 'Creating value for multiple stakeholders: sustainable business models at the base of the pyramid'. Journal of Cleaner Production, 196, pp1600-1612

Dües, C.M., Tan, K.H. and Lim, M. (2013) "Green as the new lean: How to use Lean practices as a catalyst for greening your supply chain", Journal of Cleaner Production, Vol 40 No. 1, pp93100 .

Eisenhardt, K.M. \& Martin (1989) "Making fast strategic decisions in high velocity environments", Academy of Management Journal, Vol 32 No. 3, pp543-576.

Elo, S., Kääriäinen, M., Kanste, O., Pölkki, T., Utraiainen, K. and Kyngäs, H. (2014) "Qualitative content analysis: a focus on trustworthiness", Sage Open, Vol 4 No. 1, pp1-10.

Faisal, M.N. (2010) "Sustainable supply chains: a study of interaction among the enablers", Business Process Management Journal, Vol 16 No. 3, pp508-529.

Flynn, B., Huang, X. and Zhao, X. (2015) "Supply chain management in emerging markets: critical research issues", Journal of Supply Chain Management, Vol 51 No. 1, pp3-4.

Galeazzo, A., Furlan, A. and Vinelli, A. (2013) "Lean and green in practice: interdependencies and performance of pollution prevention strategies", Journal of Cleaner Production, Vol 85, pp110.

Garg, K., Kannan, D., Diabat, A. and Jha, P.C. (2015) "A multi-criteria optimization approach to manage environmental issues in closed-loop supply chain network design", Journal of Cleaner Production, Vol. 100, pp297-314.

Gebauer, H. (2011) "Exploring the contribution of management innovation to the evolution of dynamic capabilities", Industrial Marketing Management, Vol 40 No. 8, pp1238-1250. 
Getnet, H., O'Cass, A., Ahmadi, H. and Siahitri, V. (2019) 'Supporting product innovativeness and customer value at the bottom of the pyramid through context-specific capabilities and social ties'. Industrial Marketing Management, pp70-80

Golicic, S. and Smith, C.D. (2013) "A meta-analysis of environmentally sustainable supply chain management practices and firm performance", Journal of Supply Chain Management, Vol 49 No. 2, pp 78-95.

Graham, S (2018) 'Antecedents to environmental supply chain strategies: the role of internal integration and environmental leaning'. International Journal of Production Economics, 197 pp283-296

Grant, R.M. (1991) "The resource-based theory of competitive advantage: implications for strategy formulation", California Management Review, Vol 33 No. 3, p114-136.

Hajmohammad, S., Vachon, S., Klassen, R.D. and Gavronski, L. (2013) "Lean management and supply management: their role in green practices and performance", Journal of Cleaner Production, Vol 39 No.1, pp312-320.

Hall, J. and, Vredenburg, H. (2004) "Sustainable development innovation and competitive advantage: implications for business, policy and management education", Innovation, Vol 6 No. 2, pp129140.

Hahn, R. and Kühnen, M. (2013) "Determinants of sustainability reporting: a review of results, trends, theory and opportunities in an expanding field of research", Journal of Cleaner Production, Vol 59. pp5-21.

Hart, S.L. (1995) “A natural-resourced-based view of the firm”, Academy of Management Review, Vol 20 No. 4, pp986-1014.

Hart, S.L. (1997) "Beyond greening: strategies for a sustainable world", Harvard Business Review, Vol 75 No. 1, pp 68-75.

Hart, S.L. \& Christensen, C.M. (2002) "The great leap: Driving innovation form the base of the pyramid", MIT Sloan Management Review, Vol 44 No. 1, pp51-56.

Hart, S.L. and Dowell, G. (2011) "A natural-resource-based view of the firm: fifteen years after", Journal of Management, Vol 37 No.5, pp1464-1479.

Hart, S.L. and Milstein, M.B. (1999) 'Global sustainability and creative destruction of industries'. Sloan Management Review, 41 (1). pp23-33

Hart, S.L., Sharma, S. and Halme, M. (2016) "Poverty, Business Strategy and Sustainable Development", Organization \& Environment, Vol 29 No. 4, pp401-415.

Helfat, C., Finkelstein, S., Mitchell, W., Peteraf, M.A., Singh, H., Teece, D.J. and Winter, S.G. (2007) Dynamic capabilities: understanding strategic change in organisations, Blackwell: Oxford.

Hitt, M.A., Xu, K. and Carnes, C.M. (2015) "Resource based theory in operations management research", Journal of Operations Management, Vol 41, pp77-94.

Hong, J. Zhang, Y. and Ding, M. (2018) 'Sustainable supply chain management practices, supply chain dynamic capabilities and enterprise performance'. Journal of Cleaner Production, 172, pp3508-3519

Hsieh, H. and Shannon, S.E. (2005) "Three approaches to qualitative content analysis", Qualitative Health Research, Vol 15 No. 9, pp1277-1288.

Jensen, J.L. \& Remmen, A. (2013) "Enabling circular economy through product stewardship", Prodecia Manufacturing, Vol 8, pp377-384.

Johnsen, T.E., Howard, M. and Miemczyk, J. (2014) Purchasing and supply chain management: a sustainability perspective. London: Routledge

Jumadi, H. and Zailani, S. (2010) "Integration green innovations in logistics services towards logistics services sustainability: a conceptual paper", Environmental Research Journal, Vol 4 No. 4 , pp261-271.

Kähkönen, A., Lintukangas, K. and Hallikas, J. (2018) "Sustainable supple management practices: making a difference in a firm's sustainability performance", Supply Chain Management: an International Journal, Vol 23 No. 6, pp518-530. 
Khalid, R.U., Seuring, S., Beske, P., Land, A., Yawar, S.A. and Wagner, R. (2015) "Putting sustainable supply chain management into base of the pyramid research", Supply Chain Management: an International Journal, Vol 20 No. 6, pp681-696.

Klassen, R.D. and Vereecke, A. (2012) "Social issues in supply chains: capabilities link responsibility, risk (opportunity) and performance", International Journal of Production Economics, Vol140, pp103-115.

Lee, K. and Min, B. (2015) "Green R\&D for eco-innovation and its impact on carbon emissions and firm performance", Journal of Cleaner Production, Vol 108 Part A, pp534-542.

Li, D. and Liu, J. (2014) "Dynamic capabilities, environmental dynamism and competitive advantage: evidence from China", Journal of Business Research, Vol 67 No. 1, pp2793-2799.

Lockett, A., Thompson, S. and Morgensten, U. (2009) "The development of the resource-based view of the firm: a critical appraisal", International Journal of Management Reviews, Vol 11 No. 1, pp9-28.

Lombard, M., Snyder-Duch, M. and Bracken, C.C. (2002) "Content analysis in mass communication: assessment and reporting of intercoder reliability", Human Communication Research, Vol 28 No. 4, pp587-604.

London, T. and Hart, S.L. (2004) "Reinventing strategies for emerging markets: beyond the transitional model”, Journal of International Business Studies, Vol 5, pp350-370.

Malhotra, M.K. and Mackelprang, A.W. (2012) "Are internal manufacturing and external supply chain flexibilities complementary capabilities”, Journal of Operations Management, Vol 30 No. 3, pp180-200.

Markley, M.J. and Davis, L. (2007) "Exploring future competitive advantage through sustainable supply chain management", International Journal of Physical Distribution and Logistics Management, Vol 37 No. 9, pp763-774.

Matopoulos, A., Barros, A.C. and Van der Vorst, J. (2014) "Resource-efficient supply chains: a research framework, literature review and research agenda", Supply Chain Management, Vol 20 No. 2, pp218-236.

McDougall, N., Wagner, B. and MacBryde, J. (2019) "An empirical explanation of the natural-resourcebased view of the firm", Production, Planning \& Control, Vol 30 No. 16, pp1-17.

Mencug, B. \& Ozanne, L.K. (2005) "Challenges of the 'green imperative': a natural-resource-based approach to the environmental orientation-business performance relationship", Journal of Business Research, Vol 58 No. 4, pp440-438.

Miemczyk, J. (2012) “An agenda for sustainable operations and supply chain management research", Brazilian Journal of Operations and Production Management, Vol 9 No. 2, pp1-11.

Miemczyk, J., Johnsen, T.E. and Howard, M. (2016) "Dynamic development and execution of closedloop supply chains: a natural resource-based view" Supply Chain Management: An International Journal, Vol 21 No. 4 pp453-469.

Minbashrazgah, M.M. and Shabani, A. (2019) 'Eco-capability role in healthcare facility's performance: natural-resource-based view and dynamic capabilities paradigm'. Management of Environmental Quality, 30 (1) pp137-156

Nath, P., Nachiappan, S. and Ramanthan, R. (2010) "The impact of marketing capability, operations capability and diversification strategy on performance: a resource-based view", Industrial Marketing Management, Vol 39 No. 2, pp317-329.

Newbert, S.L. (2007) "Empirical research on the resource-based view of the firm: an assessment and suggestions for future research", Strategic Management Journal, Vol 28 No. 2, pp121-146.

Pagel, M. and Shevchenko, A. (2014) "Why research in sustainable supply chain management should have no future", Journal of Supply Chain Management, Vol 50 No. 1, pp44-55

Penrose, E.T. (1959) The Theory of the Growth of the Firm. New York: John Wiley

Pernick, R. and Wilder, C. (2007) The Clean-Tech Revolution. New York: Harper Collins 
Perotti, S., Zorzini, M., Cagno, E. and Micheli, G.J.L. (2012) "Green supply chain practices and company performance: the case of the 3PLs in Italy", International Journal of Physical Distribution and Logistics Management, Vol 42 No. 7, pp640-672.

Prahalad, C.K. and Hart, S.L. (2002) "The fortune at the bottom of the pyramid", Strategy \& Business, Vol 26 No. 2, pp1-23.

Prajogo, D. and Sohal, A. (2013) "Supply chain professionals: A study of competencies, use of technologies and future challenges", International Journal of Operations and Production Management, Vol 33 No. 11/12, pp1532-1554.

Priem, R.L. and Butler, J.E. (2001) "Is the resource-based "view" a useful perspective for strategic management research?", Academy of Management Review, Vol 26 No. 1, pp22-40.

Polonsky, M.J. (1995) “A stakeholder theory approach to designing environmental marketing strategy", Journal of Business \& Industrial Marketing, Vol 10 No. 3, pp29-46.

Powell, T.C. (1992) "Strategic planning as competitive advantage", Strategic Management Journal, Vol 13 No. 7, pp551-558.

Rashidirad, M., Soltani, E. and Salimian, H. (2015) "Reductionist and holistic views of resource based theory: a review of the literature", Strategic Change, Vol 24. No. 6, pp509-525.

Russo, M.V. and Fouts, P.A. (1997) "A resource-based perspective on corporate environmental performance and profitability", Academy of Management Journal, Vol 40 No. 3, pp534-559.

Sakarya, S., Bodur, M., Yildirim-Öktem, O. and Selekler-Göksen, N. (2012) "Social alliances: business and social enterprise collaboration for social transformation", Journal of Business Research, Vol 65 No. 12, pp1710-1720.

Sarkis, J., Zhu, Q. and Lai, K. (2011) "An organisational theoretic review of green supply chain management literature", International Journal of Production Economics, Vol 130 No. 1, pp115.

Schrettle, S., Hinz, A., Scherrer-Rathje, M. and Friedli, T. (2014) "Turning sustainability into action: explaining firms' sustainability efforts and their impact on performance" International Journal of Production Economics, Vol 147, pp73-84

Seuring, S. and Müller, M. (2008) "From a literature review to a conceptual framework for sustainable supply chain management”, Journal of Cleaner Production, Vol 16 No. 15, pp1699-1710.

Shi, V.G.. Koh, L., Baldwin, J. and Cucchiella, F. (2012) "Natural resource based green supply chain management", Supply Chain Management: An International Journal, Vol 17 No. 1, pp54-67.

Strauss, K., Lepoutre, J. and Wood, G. (2017) "Fifty shades of green: how microfoundations of sustainability dynamic capabilities vary across organizational contexts", Journal of Organizational Behaviour, Vol 38 No. 9, pp1388-1355.

Svensson, G. and Wagner, B. (2012) "Implementation of a sustainable business cycle: the case of as Swedish dairy producer”, Supply Chain Management: An International Journal, Vol 17 No. 1, pp93-97.

Tate, W.L. and Bals, L. (2018) 'Achieving shared triple bottom line (TBL) value creation: towards a social resource-based view (SRBV) of the firm'. Journal of Business Ethics, 152 (3) pp803826

Teece, D.J. (2007) "Explicating dynamic capabilities: the nature and micro-foundations of (sustainable) enterprise performance", Strategic Management Journal Vol 28 No. 13, pp1319-1350.

Teece, D.J., Pisano, G. and Shuen, A. (1997) "Dynamic capabilities and strategic management", Strategic Management Journal, Vol 18 No. 7, pp509-533.

Tranfield, D. Denyer, D. and Smart, P. (2003) "Towards a methodology for developing evidenceinformed management knowledge by means of systematic review" British Journal of Management, Vol 14 No. 3, pp207-222.

Vachon, S. (2007) "Green supply chain practices and the selection of environmental technologies", International Journal of Production, Vol 45 No. 18-19, pp4357-4379. 
Vachon, S. and Klassen, R.D. (2008) "Environmental management and manufacturing performance: The role of collaboration in the supply chain", International Journal of Production Economics, Vol 111 No. 2, pp299-315.

Wernerfelt, B. (1984) “A resource-based view of the firm”, Strategic Management Journal, Vol 5 No. 2, pp171-180.

Winter, S.G. (2003) "Understanding dynamic capabilities", Strategic Management Journal, Vol 24, No. 10, pp991-996.

Yang, Y., Fia, F. and Xu, Z. (2018) "Towards an integrated conceptual model for supply chain learning: an extended resource based view", Supply Chain Management: an International Journal, Vol 24 No. 2, pp189-214.

Yang, Z. and Su, C. (2014) "Institutional theory in business marketing: a conceptual framework and future directions", Industrial Marketing Management, Vol 43 No. 5, pp721-725.

Zollo, M. and Winter, S.G. (2002) "Deliberate learning and the evolution of dynamic capabilities" Organizational Science, Vol 3 No. 13, pp339-351. 